\title{
Occurrence of Intersexuality in "Lambaris", Astyanax scabripinnis (Jenyns, 1842), Small Characids from the Brazilian Streams
}

\author{
Maria de Fátima Pereira de Sá ${ }^{1 *}$, Evelise Nunes Fragoso-Moura ${ }^{2}$, Nelsy Fenerich-Verani ${ }^{2}$ \\ and Dagmar Aparecida de Marco Ferro ${ }^{3}$ \\ ${ }^{1}$ ICBS; Universidade Federal de Alagoas; Praça Afrânio Jorge, s/n; 57010-020; fa.persa@gmail.com; Maceió - AL \\ - Brasil. ${ }^{2}$ Departamento de Hidrobiologia; Universidade Federal de São Carlos; C. P.: 676; 13565-906; São Carlos \\ - SP - Brasil. ${ }^{3}$ Faculdades Integradas de Santa Fé do Sul; Av. Mangará, 477; 15775-000; Santa Fé do Sul - SP - \\ Brasil
}

\begin{abstract}
During studies carried out with a small characid (Astyanax scabripinnis), from the Brazilian streams located in Cerrado biome, some gonads of fishes exhibited sparse oocytes in perinucleolar stage embedded in normally developing testicular tissues. Another pattern of gonad intersex with vitellogenic oocytes and mature lobules was observed in the gonads of fishes collected from a reservoir supplied by the Atlantic Forest stream. These gonads in different stages of maturation were examined histologically. The results revealed the patterns occurring in fishes of the same species, from four different populations.
\end{abstract}

Key Words: Intersexuality, Neotropical ichthyofauna, Characidae, Tetras, Stream fishes

\section{INTRODUCTION}

Among the Characiformes, the freshwater fishes of the family Characidae and its subfamily Tetragonopterinae, the so-called South American tetras (Nelson, 1994), have the largest richness of species. This is a paraphyletic group predominating in the streams of several Brazilian hydrographic basins (Buckup, 1998). Among the Tetragonopterinae, Astyanax scabripinnis (Jenyns, 1842), known as "lambari" is frequently found in the small streams (Castro and Casatti, 1997), particularly in the headwaters (Moreira Filho and Bertollo, 1991). Several studies on this species have been performed for geographically isolated populations from small tributaries located in mountain regions of two major Brazilian biomes: the "Cerrado" (savannah type formation) and the Atlantic Forest (Britski et al., 1988; Moreira Filho and Bertollo, 1991; Barbieri, 1992; Néo et al., 2000; Veregue and Orsi, 2003). Based on the morphological and kariotypic characteristics, Moreira-Filho and Bertollo (1991) proposed that these A. scabripinnis populations might constitute a species complex.

In studies carried out on $A$. scabripinnis populations by Fenerich-Verani et al. (1997); Ferro et al. (2001), Ferro et al. (2003), Fragoso (2000), Sá et al. (2000) and Sá (2000), intersex gonads have been repeatedly found. Chan and Yeung (1983) also reported this, whereby animals possessed both the male and female gonadal

\footnotetext{
* Author for correspondence
} 
tissues, considering it an abnormal occurrence in gonochoristic species of the fishes. In fact, intersexuality is very infrequently observed under natural or normal breeding conditions and, as might be expected, according to Quillet et al. (2004), very little is known about the physiological mechanisms of gonad differentiation in spontaneous intersex individuals recorded for gonochoristic species.

Although not usual, except for undifferentiated species (Yamamoto, 1969), several studies have already reported the occurrence of intersexuality in a few individual from gonochoristic fishes: Cyprinus carpio (Gupta and Meske, 1976), Rutilus rutilis (Jafri and Ensor, 1979; Lukšienè et al., 2000; Nolan et al., 2001), Thymallus thymallus (Blachuta et al., 1991), Salvelinus alpinus (Fraser, 1997), Acipenser oxyrinchus (Van Eenennaam and Dorosov, 1998), Esox lucius (Lukšienė et al., 2000), and Oncorhynchus mykiss (Quillet et al., 2004). Except for O. mykiss, which presented an overall frequency of $5.4 \%$, the frequency of occurrence was usually low, varying from 0.1 to $0.6 \%$.

Nevertheless, some studies have reported intersex percentage values higher than $10 \%$ in wild populations of Esox lucius (Vine et al., 2005), Gasterosteus aculeatus and Perca fluviatilis (Gerchen and Sordyl, 2002), and Xiphias gladius (DeMetrio, 2003). In the present paper, the occurrence of intersexuality is reported for some Astyanax scabripinnis individuals collected in wild populations from streams in Minas Gerais State and in a reservoir in São Paulo State, Southeastern region of Brazil.

\section{MATERIALS AND METHODS}

Specimens of three populations of A. scabripinnis, were sampled from three streams situated in the savannah region of the adjoining states of Minas Gerais and São Paulo, as well as in a reservoir receiving headwaters from some highlands in the Atlantic Forest mountain region of São Paulo State. Fishes were collected using a trawl net $(4.20 \mathrm{~m} \times 0.95 \mathrm{~m})$ with $1 \mathrm{~mm}$ mesh in the "Curral das Éguas" stream (18 $07^{\circ} 11^{\prime}$ 'S and $42^{\circ} 25^{\prime} 09^{\prime}$ ' $W$ ), located in Minas Gerais State in the Central region of Brazil. The stream watershed included areas used for cattle farming and agriculture. Using the same type of net, fishes were also sampled in "Fazzari" $\left(21^{\circ} 58^{\prime} 08^{\prime}\right.$ 'S and $\left.47^{\circ} 53^{\prime} 09^{\prime \prime} \mathrm{W}\right)$ and "Lagoa" (21 $1^{\circ} 56^{\prime} 12^{\prime \prime} \mathrm{S}$ and $47^{\circ} 54$ ' $15^{\prime}$ 'W) streams located on the "Cerrado" of the São Paulo State (Southeastern Brazil). The streams cross cattle areas, where chemical substances are used. "Lagoa" stream presents a stretch that consists in a cattle drinking place, with detritus accumulation. The fish from "Capivari" ( $22^{\circ} 43^{\prime} 00^{\prime \prime} \mathrm{S}$ and $\left.45^{\circ} 34^{\prime} 00^{\prime \prime} \mathrm{W}\right)$ - a stream inside Atlantic Forest - were captured in a reservoir located in the central urban area of Campos de Jordão town- a famous touristic center. The reservoir receives inputs from agricultural areas drainage and is also used by local population for recreational purposes.

After biometry and ventral incision, the gonadal maturation stage and sex were identified macroscopically. Gonads were removed by dissection and weighted before fixation in Bouin's fluid or glutaraldehyde (GTA). Small fish $(L T<3.5$ $\mathrm{cm})$ were fixed whole in order to avoid damaging the gonads. Due to their reduced size, even in the larger fish $(L T=9.4 \mathrm{~cm})$, whole gonads were embedded in either paraffin wax or glycol methacrylate plastic resin. After $5 \mu \mathrm{m}$ sectioning transversally or longitudinally, staining was carried out with hematoxylin-eosin (HE) or methylene blue plus fucsine. The sections were examined by light microscopy. For each fish, the gonadal development stage and cell type were recorded.

\section{RESULTS}

The maximum total length $(L T)$ recorded in the studied populations of Astyanax. scabripinnis was $9.4 \mathrm{~cm}$. Microscopic analysis involved 219 fish gonads from the Curral das Éguas Stream; as well as 247 fish from the Fazzari, 228 from the Lagoa, and 41 from the Capivari streams. The gonads of this species were paired structures fixed to the body cavity, as observed in the majority of teleost fishes. While the testes were of the lobular type described by Grier and Taylor (1999), the ovaries were cystovarian (like those described by Takashima and Hibiya, 1995). The normal developmental pattern of the ovaries of $A$. scabripinnis regarding all the populations studied was asynchronic (sensu Nagahama, 1983), with oocytes in different developmental stages during the year, which were typical of species spawning several times in an annual cycle. An asynchronic 
developmental pattern of the testis was also observed.

In this study, some gonads showed intersex characters under microscopic examination. Four intersex fish were found in the Curral das Éguas Stream (1.9\%), six in the Fazzari $(2.4 \%)$, five in the Lagoa (2.2\%) and four in the Capivari streams $(9.8 \%)$. Intersex fishes from all the streams were microscopically identified as males with testes in different maturation stages (resting, maturation, and mature). The predominance of testicular tissue, with oocytes in perinucleolar stage inserted in the lobular wall (Figs. 1a, b, c and 2a, b), was observed in these fish. The fish from the Capivari stream presented yet another pattern of intersexuality, when both gonads of a single fish had distinct areas with the male and female germinative cells in the mature stage (Fig. 3).

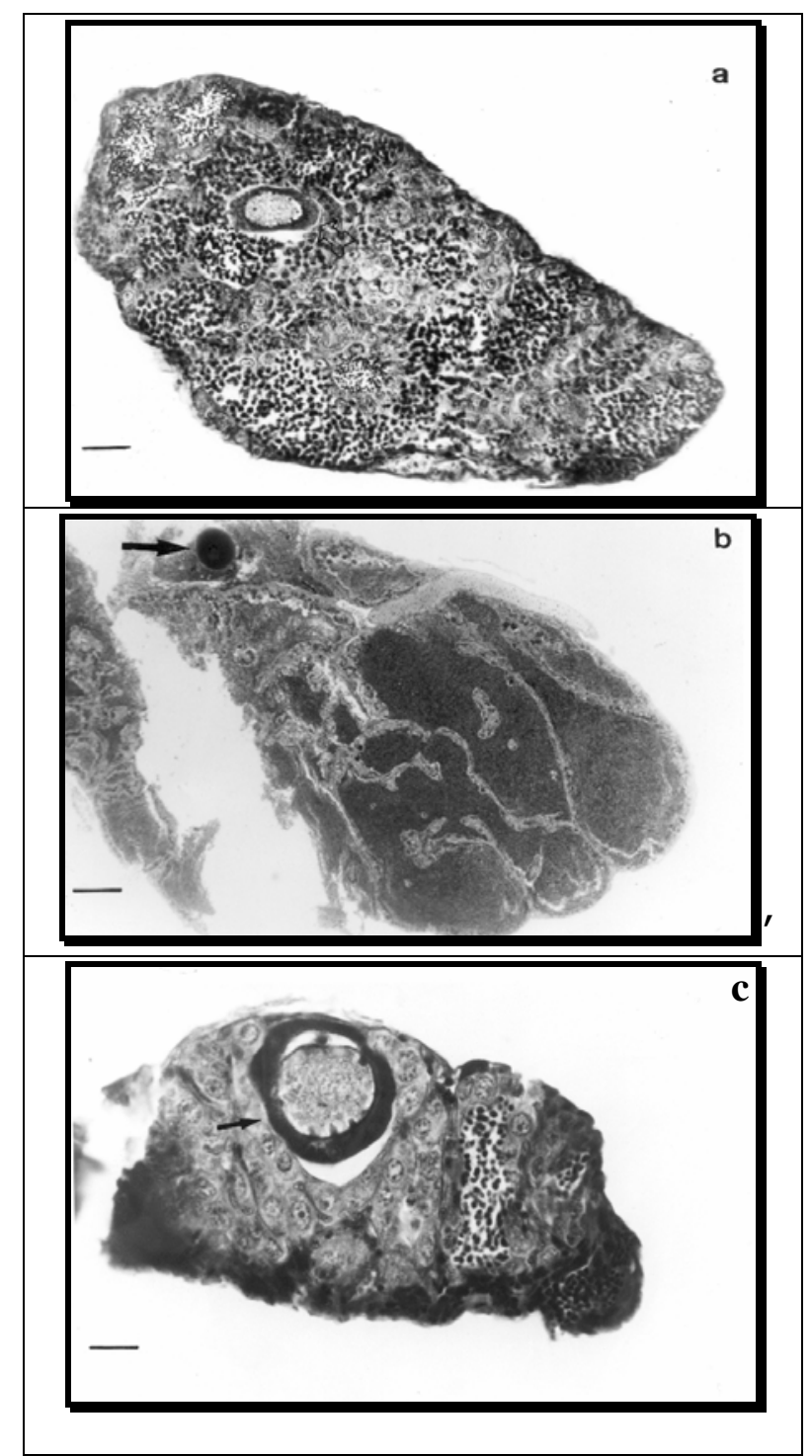

Figure 1 - Testes of Astyanax scabripinnis from the Curral das Éguas Stream, identified as males, showing ovarian follicles with perinucleolar stage oocytes (a) advanced maturation stage [HE; scale bar: $40 \mu \mathrm{m}$ ]; (b) mature stage [methilene blue plus fucsine; Scale bar: $200 \mu \mathrm{m}$ ]; (c) initial maturation stage [HE; scale bar: $20 \mu \mathrm{m}$ ] 


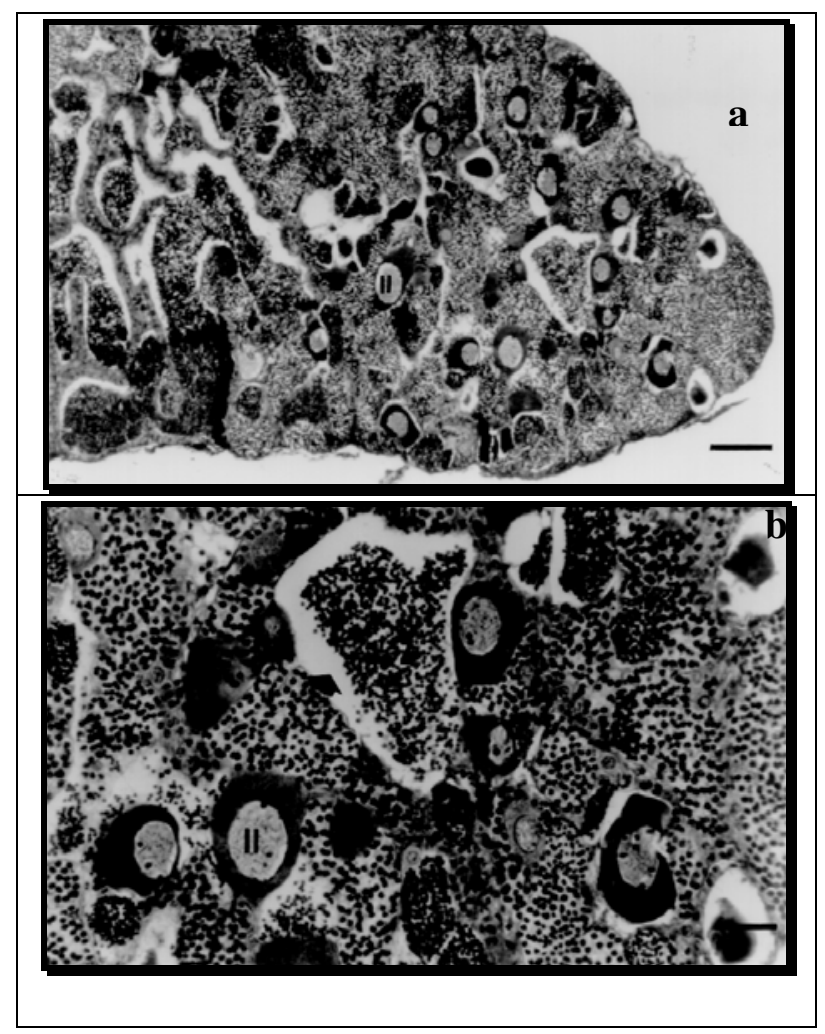

Figure 2 - Testes of Astyanax scabripinnis from Lagoa Stream, identified as males, (a) in advanced maturation stage, showing perinucleolar stage oocytes (II) [HE; scale bar: $100 \mu \mathrm{m}$ ]; (b) a detail showing oocytes (II) in the walls of the lobules [HE; Scale bar: $40 \mu \mathrm{m}$ ]

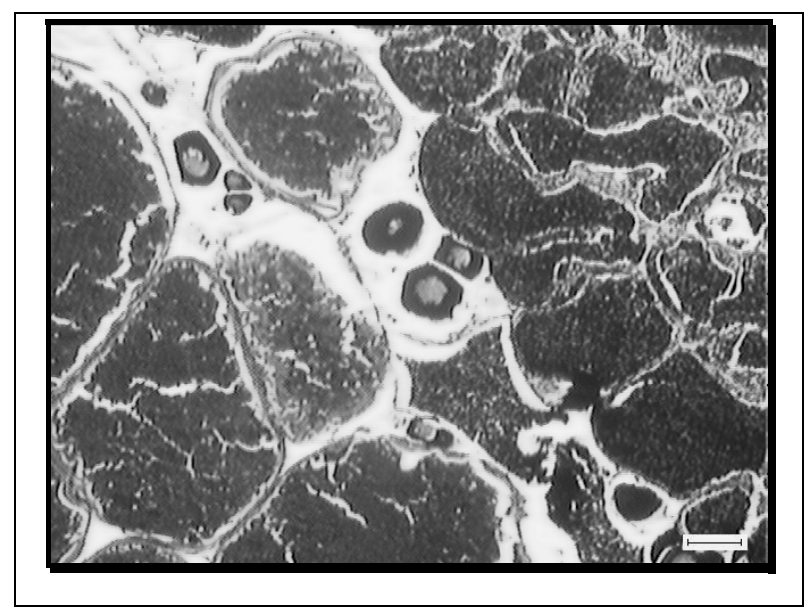

Figure 3 - Testes of Astyanax scabripinnis from the Capivari Stream, identified as males, showing vitellogenic oocytes (left) and spermatozoa (right) in same gonad [HE; scale bar: $100 \mu \mathrm{m}$ ] 


\section{DISCUSSION}

Common among the fishes, the hermaphroditism is a normal mode of reproduction, related to 34 families of teleosts (Kuwamura and Nakashima, 1998) that present, especially in reef fishes, a diversity of patterns that can be either sequentially (protandrous or protogynous fishes) or simultaneously hermaphroditic. There are several theories about the adaptative significance of sex change in those teleosts that normally signals hermaphroditism (Robertson and Warner, 1978; Fischer and Hardison, 1987; Lejeune, 1987; Shapiro, 1987; Siau, 1994; Sadovy and Donaldson, 1995).

The occurrences observed in the present study were not common cases of hermaphroditism, but they could be more accurately described as intersexuality. According to Yamamoto (1969), intersex is the term used to denote either sporadically appearing or experimentally produced hermaphroditic individuals of a species in which all or nearly all individuals are gonochoristic. Characids species are considered to be gonochoristic.

There are several records of intersexuality among gonochoristic species. In an experimental study of reproduction in Rutilus rutilus (L.), Jafri and Ensor (1979) registered a condition of apparently functional intersexuality during the microscopical examination of a testis exhibiting normal stages of spermatogenesis.

In Astyanax scabripinnis, there were cysts of small oogonia in the chromatin-nucleolus stage, while a few larger oocytes in the perinucleolar stage were situated beside the cyst or randomly scattered throughout the testis itself, as observed experimentally in $R$. rutilus. The occurrence of testicular and ovary tissues in the same gonad, characterized by the presence of vitelogenic oocytes and mature male germinative cells, was observed in the present study. In Cyprinus carpio, Gupta and Meske (1976) described a similar structure, which they named the ovotestis.

The evolution of sex change as an alternative style on the life history of gonochorist fishes has been explained by the size-advantage model (Ghiselin, related by Chan and Yeung, 1983). Tobin et al. (1997) reported that the simple presence of intersex or transitional tissues in the gonads of histologically examined fishes did not provide direct evidence of a sex change process. Bruslé and Bruslé (1983) emphasized that the presence of intratesticular oocytes did not constitute a sufficient argument for differentiation of the indirect type. Nolan et al. (2001) presented a study based on 150 intersex individuals of a gonochoristic species, Rutilus rutilus, collected from some British rivers. This impressive and well-known record has been attributed to the exposition of those fishes to endocrine-disrupting substances present in the effluents of the British rivers, lakes, and streams. However, according to the authors, the functional significance and the reproductive consequences of intersex in $R$. rutilus remain to be determined.

In a large-scale sampling study of rainbow trout Oncorhynchus mykiss spontaneous intersexes, Quillet et al. (2004) found that this was usually considered teratological. Although, according to these authors, environmental factors could be the possible causes, intersex condition in rainbow trout was interpreted due to sex-modifying genetic factors. Fraser (1997) mentioned studies that showed increasing evidence that alkylphenol polyethoxylates, a group of compounds widely used in industrial and agricultural processes, when introduced into the aquatic environments through sewage effluents, were responsible for promoting vitellogenesis in the male fish resulting in feminization of the reproductive organs. Lukšiene et al. (2000) observed that high temperatures in the thermal effluent area at the nuclear power plant in Swedish and Lithuanian negatively influenced the gametogenesis in Perca fluviatilis, Rutilus rutilus and Esox lucius females, thus provoking hermaphroditism among other alterations observed. Jobling et al. (2002) demonstrated that male gamete production and male gamete quality were reduced in intersex roach (Rutilus rutilus) living in rivers with a history of contamination from treated sewage effluents known to contain estrogenic contaminants. Intersex was not observed in hatchery-reared white perch or in white perch collected by Kavanagh et al. (2004) from an uncontaminated reference site in the United States.

In the present work, it was observed that the intersexuality occurrences in the populations were inside the range observed for other species, as found in the literature: from 0.1\% (Jafri and Ensor, 1979; Fraser, 1997; van Eenennaam and Dorosov, 
1998; Lukšienė et al., 2000; Barnhoorn et al., 2004) to $25 \%$ (De Metrio et al., 2003) or more (Gercken and Sordyl, 2002; Kavanagh et al., 2004). However, it was noteworthy that the highest frequency of intersex $(9.8 \%)$ was recorded for the fish population collected in Capivari stream, the water outflow from an urban reservoir receiving both, the agricultural runoff and the domestic sewage from a touristic town.

Barnhoorn et al. (2004) found intersexuality in $20 \%$ of catfish (Clarias gariepinus) collected ramdomly from the two dams, which received drained waters from a stream that received effluent from the industrial sites, agricultural activities, informal settlements, and municipal treatment plants. Chemical analyses showed high values of p-nonylphenol (p-NP) in the water and sediment of these dams, indicating estrogenic water pollution. According to Barnhoorn et al. (2004), commonly found in the effluent from sewage treatment plants, p-NP might affect wildlife and human dependent on these sources.

To assess the estrogenicity of a municipal sewage treatment plant, Diniz et al. (2005) exposed sexually mature crucian carp (Carassius carassius) for 28 days to domestic treated sewage effluent (25, 50 and $100 \%)$. Morphological changes were detected by histological evaluation, revealing severe effects on the testes, with spermatogenesis progressively reduced to total inhibition in fish exposed to $100 \%$ effluent. The presence of oocytes was detected in $20 \%$ of the males exposed to $100 \%$ sewage effluent.

In order to explain the evidence for sexual disruption, van Aerle et al. (2001) collected specimens of Gobio gobio from the rivers in the United Kingdom, in several locations that received high-volume discharges of sewage treatments work. Intersex gonads were found at all the sites, but the highest incidences (12 to $15 \%$ ) occurred at one of places with still water; the elevated concentrations of plasma vitellogenin indicated that fish had been exposed to estrogens.

De Metrio et al. (2003) reported evidence of a high percentage of intersex $(25 \%)$ in a wild population of Mediterranean swordfish (Xiphias gladius) and immunohistochemically demonstrated the presence of vitellogenin in the liver of both, intersex and normal males. According to the authors, these findings could be due to the exposure to endocrine disrupting substances that promoted estrogenic effects. Man-made chemicals are among the substances causing environmental pollution. These endocrine-disrupting substances (EDSs), according to Kavanagh et al. (2004), are from industrial origin, such as alkylphenol surfactants, bisphenol A, and phthalate plasticizers, beyond include natural estrogens, such as $17 \beta\left(\mathrm{E}_{2}\right)$ and estrone, and the syntetic estrogen $17 \alpha$-ethinyllestradiol $\left(\mathrm{EE}_{2}\right)$. These authors opened the question on the risk to human health of consumption of fishes containing bioaccumulated endocrine disrupters. These alterations were not restricted to Mediterranean region and to fish population, but there is a vast literature about this problem concerning to different regions of the world and different groups of animals. Colborn et al.. (1997) provided information of emerging scientific research on animal and human studies carried out in the world that linked the wide range of manmade chemicals and the disruptions of hormone systems.

In the present study, the intersex occurrences observed in the wild populations of A.scabripinnis from four different localities were not conclusive regarding the causes. In a general way, the possible action of toxic agents present in the environments could not be ruled out. Nevertheless, experimental studies are necessary to provide a basis for constructing an explanatory hypothesis to the occurrence of intersexuality in the populations of $A$. scabripinnis here analyzed.

\section{ACKNOWLEDGEMENTS}

This work was possible through two informal agreements between the Federal University of São Carlos (UFSCar) and the Companhia de Desenvolvimento do Vale do São Francisco e do Parnaíba (CODEVASF) (Três Marias, MG, Brazil) and Empresa Brasileira de Pesquisa Agropecuária (São Carlos, SP, Brazil). The first and second authors were granted postgraduate scholarships from the Coordenadoria de Aperfeiçoamento de Pessoal do Ensino Superior (CAPES) / Education Ministry of Brazil. We thank Dra. O. Rigolin-Sá for the histological slides and Dr. Y. Sato for logistic support. We are grateful to the anonymous reviewers by the valuable suggestions. 


\section{RESUMO}

Durante estudos efetuados com pequenos caracídeos (Astyanax scabripinnis) de riachos do Cerrado brasileiro, localizados nos Estados de Minas Gerais e de São Paulo, foram encontrados alguns peixes com gônadas exibindo oócitos em estágio perinucleolar dispersos, embebidos em tecidos testiculares em desenvolvimento. Em exemplares da mesma espécie, provenientes de um riacho situado na Mata Atlântica do Estado de São Paulo, outro padrão de gônadas intersexuadas foi registrado, mostrando oócitos vitelogênicos e lóbulos maduros presentes na mesma gônada. As gônadas em diferentes estágios de maturação foram submetidas a análises histológicas. Os resultados obtidos mostram os padrões morfológicos e as freqüências de ocorrência dos intersexos encontrados em peixes do "complexo" A. scabripinnis provenientes de quatro diferentes populações. São discutidas as prováveis causas ambientais responsáveis por estas alterações.

\section{REFERENCES}

Barbieri, G. (1992), Biologia de Astyanax scabripinnis paranae (Characiformes, Characidae) do ribeirão do Fazzari, São Carlos, Estado de São Paulo. II Aspectos quantitativos da reprodução. Revista Brasileira de Biologia, 52, 589-596.

Barnhoorn, I. E., Bornman, M. S. Pieterse, G. M. and Vuren, J. H., Histological evidence of intersex in feral sharptooth catfish (Clarias gariepinsu) from an estrogen-polluted water source in Gauteng, South Africa. Environ Toxicol., 6, 603-608.

Blachuta, J., Witkowski, A. and Kokurewicz, B. (1991), A hermaphrodite grayling, Thymallus thymallus (L.), from the Nysa Klodzka river (Lower Silesia, Poland). Journal of Fish Biology, 38, 955-957.

Britski, H. A., Sato, Y. and Rosa, A. B. S. (1988) Manual de identificação de peixes da região de Três Marias: com chaves de identificação para os peixes da Bacia do São Francisco. Câmara dos Deputados / CODEVASF, Brasília.

Bruslé, J. and Bruslé, S. (1983), La gonadogènese des poissons. Reproduction Nutrition Development, 23, 453-491.
Buckup, P. A. (1998), Relationships of the Characidiinae and phylogeny of Characiform fishes (Teleostei: Ostariophysi). In-Phylogeny and classification of Neotropical fishes, eds. L. R. Malabarba, R. Reis, R. P. Vari, Z. M. S. Lucena and C. A. S. Lucena. EDIPUCRS, Porto Alegre, pp. 123144.

Colborn, T., Dumanoski, D. and Myers, J. P. (1997). Our stolen future. Penguin Books, New York. 316 p.

Castro, R. M. C. and Casatti, L. (1997), The fish fauna from a small forest stream of the upper Paraná River basin, southeastern Brazil. Ichthyol. Explor. Freshwaters, 7, 337-352.

Chan, S. T. H. and Yeung, W. S. B. (1983), Sex control and sex reversal in fish under natural conditions. InFish Physiology. V.9, part B, eds. W. S. Hoar, D. J. Randall and E. M. Donaldson, Academic Press, London, pp.171-222.

De Metrio, G., Corriero, A., Desantis, S., Zubani, D., Cirillo, F., Deflorio, M., Bridges, C. R., Eicker, J., de la Serna, J. M., Megalofonou P., and Kime, D. E. (2003), Evidence of a high percentage of intersex in the Mediterranean swordfish (Xiphias gladius L.). Marine Pollution Bulletin, 46, 358-361.

Diniz, M. S., Peres, I., Magalhães-Antoine, I, Falla, J. and Pihan, J. C. (2005), Estrogenic effects in crucian carp (Carassius carassius) exposed to treated sewage effluent. Ecotoxicol Environ Saf., 3, 427-435.

Fenerich-Verani, N., Fragoso, E. N., Godoy, L. C. and Di Giovanni, P. C. (1997), Gonadal characterization of the lambari Astyanax scabripinnis (Characiformes, Characidae) of the Fazzari stream, São Carlos/SP, Brazil: histological analysis. Paper presented at International Symposium Biology of Tropical Fishes, 6-8 October, Manaus, INPA.

Ferro, D. A. M., Moreira-Filho, O. and Bertollo, L. A. C. (2003), B chromosome polymorphism in the fish, Astyanax scabripinnis. Genética, 119, 147-153.

Ferro, D. A. M., Néo, D. M., Moreira-Filho, O. and Bertollo, L. A. C. (2001), Nucleolar organizing regions, $18 \mathrm{~S}$ and 5S rDNA in Astyanax scabripinnis (Pisces, Characidae): population distribution and functional diversity. Genetica, 110, 55-62.

Fischer, E. A. and Hardison, P. D. (1987), The timing of spawning and egg production as constraints on male mating $I$ in a simultaneously hermaphroditic fish. Environmental Biology of Fishes, 20, 301-310.

Fragoso, E.N. (2000), Caracterização biológica de Astyanax scabripinnis paranae (Eigenmann, 1914) (Characiformes, Characidae) do córrego da Lagoa, São Carlos/SP. Master Dissertation, Federal University of São Carlos, São Carlos-SP, Brazil.

Fraser, D. (1997), A hermaphroditic Artic charr from Loch Rannoch, Scotland. Journal of Fish Biology 50, 1358-1359. 
Gercken, J. and Sordyl, H. (2002), Intersex in feral marine and freshwater fish from northeastern Germany. Marine Environmental Research. 54, 651655.

Grier, H. J. and Taylor, R. G. (1998), Testicular maturation and regression in the common snook. Journal of Fish Biology. 53, 521-542.

Gupta, S. and Meske, Ch., Abnormalities of gonads of carp. J.Fish Biol., 9, 75-77.

Jafri, S. I. H. and Ensor, D. M. (1979), Occurrence of an intersex condition in the roach Rutilus rutillus (L). Journal of Fish Biology, 14, 547-549.

Jobling, S., Coey, S. Whitmore, J. G., Kime, D. E., Van Look, K. J. W., McAllister, B. G., Beresford, N., Henshaw, A. C., Brighty, G., Tyler, C. R. and Sumpter, J. P. (2002), Wild intersex roach (Rutillus rutillus) have reduced fertility. Biology of reproduction, 67, 515-524.

Kavanagh, R. J., Balch, G. C., Kiparissis, Y., Niimi, A., Sherry, J., Tinson, C. and Metcalfe, C. D. (2004), Endocrine disruption and altered gonadal development in white perch (Morone Americana) from the Lower Great Lakes Region. Environmental Health PerspectivesI, 112, 898-902.

Kuwamura, T. and Nakashima, Y. (1998), New aspects of sex change among reef fishes: recent studies in Japan. Environmental Biology of Fishes, 52, 125-135

Lejeune, P. (1998), The effect of local stock density on social behavior and sex change in the Mediterranean labrid Coris julis. Environmental Biology of Fishes, 18, 135-141.

Luksiené, D., Sandoström, O, Lounasheimo, L and Andersson, J. (2000), The effects of thermal effluent exposure on the gametogenesis of female fish. Journal of Fish Biology, 56, 37-50.

Moreira-Filho, O. and Bertollo, L. A. C. (1991), Astyanax scabripinnis (Pisces, Characidae): a species complex. Brazilian Journal of Genetics, 14, 331-357.

Nagahama, Y. (1983). The functional morphology of teleost gonads. In: Fish physiology. V.9. eproduction. eds. W. S. Hoar, D. J. Randall and E. M. Donaldson, Academic Press, Orlando, pp. 223-275.

Nelson, J. S. (1994), Fishes of the world, John Wiley, New York.

Néo, D. M., Moreira Filho, O. and Camacho, J. P. (2000), Altitudinal variation for B chromosome frequency in the characid fish Astyanax scabripinnis. Heredity, 85, 136-141.

Nolan, M., Jobling, S. Brighty, G., Sumpter, J. P. and Tyler, C. R. (2001), A histological description of intersexuality in the roach. Journal of Fish Biology, 53, 160-176.

Quillet, E., Labbe, L. and Queau, I. (2004), Asymmetry in sexual development of gonads in intersex rainbow trout. Journal of Fish Biology. 64, 1147-1151.
Robertson, R. and Warner, R. R. (1978), Sexual patterns in the Labroid fishes of the Western Caribbean, II: the parrotfishes (Scaridae). Smithsonian Institution Press, Washington. (Smithsonian Contributions to Zoology, 255).

Sá, M. F. P. (2000), Caracterização de duas populacões de Astyanax scabripinnis (Jenyns, 1842) de riachos da Bacia do rio São Francisco. PhD Thesis, Federal University of São Carlos, São Carlos-SP, Brasil.

Sá, M. F. P., Fenerich-Verani, N., Fragoso, E.N. (2000), Caracterização das gônadas de Astyanax scabripinnis (Pisces-Characidae-Tetragonopterinae). Paper presented at $23^{\text {th }}$ Brazilian Congress of Zoology, 13-18 February, UFMT, Cuiabá.

Sadovy, Y. and Donaldson, T. J. (1995), Sexual pattern of Neocirrhites armatus (Cirrhitidae) with notes on other hawkfish species. Environmental Biology of Fishes, 42, 143-150.

Shapiro, D.Y. (1987), Patterns of space use common to widely different types of social groupings of a coral reef fish. Environmental Biology of Fishes, 18, 183194.

Siau, Y. (1994), Population structure, reproduction and sex-change in a tropical East Atlantic grouper. Journal of Fish Biology, 44, 205-211.

Takashima, F. and Hibiya, T. (1995), An atlas of fish histology: normal and pathological features. Kodansha/ Fischer, Tokyo.

Van Aerle, R., Nolan, M., Jobling, S., Christiansen, L. B., Sumpter, J. P., and Tyler, C. R. (2001), Sexual disruption in a second species of wild cyprinid fish (the gudgeon, Gobio gobio) in united kingdom freshwaters. Environmental Toxicology and Chemistry. 20, 2841-2847.

Van Eenennaam, J. P. and Doroshov, S. I. (1998), Effects of age and body size on gonadal development of Atlantic sturgeon. Journal of Fish Biology, 53, 624-637.

Veregue, A. M. L. and Orsi, M. L. (2003), Biologia reprodutiva de Astyanax scabripinnis paranae (Eigenmann) (Ostheichthyes, Characidae), do ribeirão das Marrecas, bacia do rio Tibagi, Paraná. Revista Brasileira de Zoologia, 20, 97-105.

Vine, E., Shears, J., van Aerle, R., Tyler, C. R. and Sumpter, J. P. (2003), Endocrine (sexual) disruption is not a prominent feature in the pike (Esox lucius), a top predator, living in English waters. Environ Toxicol Chem. , 6, 1436-1443.

Yamamoto, T. (1969), Sex differentiation. In: Fish Physiology. v.3. Reproduction and Growth. eds. W.S. Hoar, D.J. Randall and E.M. Donaldson, Academic Press, London, pp.117-175.

Received: September 19, 2005; Revised: October 10, 2006; Accepted: August 13, 2007. 